\title{
専門工事業者による設計協力に関する基本的考察 \\ 日米エレベータ設計をケーススタディ対象として \\ STUDY ON THE DESIGN ASSISTANCE BY JAPANESE SUBCONTRACTORS
}

Japan and the US case studies in the elevator design

\author{
小笠原 正豊*, 野城 智 也** \\ Masatoyo OGASAWARA and Tomonari YASHIRO
}

\begin{abstract}
This paper investigates so-called "Design Assistance (sekkei kyoryoku)" by Japanese subcontractors. The elevator industry is focused as the typical industry indicating the clear difference of the task distribution between Japanese Design Assistance and the US Consultation. First, the tasks and responsibilities of subcontractors in Design Assistance are clarified. We confirmed the subcontractors provide the design information based on the Design Assistance free of charge. The subcontractors do not have a primal responsibility of their design information, especially to the owner of the project. It results in a confusion of responsibilities between the architect and the subcontractor. Second, two types of the information gathering process through the Design Assistance is confirmed. One is the information generated by the subcontractor and provided to the architect, such as drawings, specifications, analysis, cost estimation, and presentation images. The other is the information provided from the architect to the subcontractor The Design Assistance is one of the best opportunities for subcontractors to acquire "needs" of the owners, which is typically not obtained by the sales department of subcontractors. It is utilized for the development of new products. Third, the difference between Design Assistance in Japan and Consultation in US are focused. In US, an assessment and inspection oriented service and project management service are available. There are far more significant opportunities in modernization than new construction. The elevator manufacturers and the vertical transportation consultants are separate entities, which make smooth information exchange difficult.
\end{abstract}

Keymords division of labor, profession, design assistance, Vertical Transportation, design information, 分業, 専門職, 設計協力, エレベータ, 設計情報

1 はじめに

\section{1 研究の背景と目的}

近年、建築物の設計業務に必要な技術的知識の多様化・高度化は 著しく、複数の設計者による設計業務の分業は不可欠である。設計 業務をマネジメントすることは、正確かつ創意工夫に富んだ設計情 報を作成する上で、大変重要な課題である。

既稿 ${ }^{1)}$ では、日米の設計分業体制の比較分析を行うことにより、 日本の設計組織において、(1)技術的専門性を持つ専門職間における 設計業務の分割が米国ほど細分化されていないこと、(2)技術的専門 性を持つ専門工事業者注 ${ }^{1}$ 等の設計チームによる設計協力を含めた 設計分業体制が編成されていること、(3)CAD 作図フォーマットは組 織設計事務所ごとに決められていて共通化されていないことを確認 した。しかし、日本の専門工事業者による設計協力と、米国の専門
職による設計業務の責任・役割および生成された設計情報に違いに ついて明らかにするには至っていない。

一般的な日本国内のプロジェクトにおいて、日本の設計者は、建 築部位や建築部品に関するカタログや施工要領書など、入手が容易 な資料を基に設計業務を行う。しかし、一般的に流通している既製 品ではなく特注品に関する設計情報を設計図書に含める必要がある 場合、建築部位や建築部品に関寸る詳細な仕様や構工法的限界やコ ストなどについて十分な設計情報が得られないため、図面や見積り や技術的検証を専門工事業者に対して依頼することが必要となる。 総合工事業者の契約相手である専門工事業者に対して設計協力を求 めることは、間接的ではあるが契約上の公正さを欠くことにつなが ると考えられる ${ }^{2)}$ 。また施工段階での発注を通じて専門工事業者を 正式に選定し、設計内容の再検討を行うことが前提となる ${ }^{3)}$ た、
* 東京大学生産技術研究所 特任助教 · 建築修

** 東京大学生产技術研究所 教授.工博
Project Assist. Prof., Institute of Industrial Science, The University of Tokyo, M. Arch. Prof., Institute of Industrial Science, The University of Tokyo, Dr. Eng. 
設計協力を行った専門工事業者が必ずしも受注できるわけではない。 このようなあいまいな状況にある専門工事業者による設計協力と、 設計専門職による設計業務との違いが十分に調查されているとは言 えない。

本稿は、設計業務のマネジメントに利活用することを前提として、 調查対象と寸る専門職種を具体的に絞り込んだ上で、(1)設計協力に 含まれる設計情報作成の責任・役割の把握、(2)設計協力により生成 される設計情報の把握、(3)日本の専門工事業者による設計協力と米 国の設計専門職による設計業務の差異の把握を目的とする。

\section{2 研究の方法}

設計業務の分業において、構造設計や設備設計のように意匠設計 と高度な統合を求められる設計業務がある一方で、独立性が高く部 分的な調整のみが必要とされる設計業務も存在する。本稿では、独 立性が高く定型化し易い設計業務であることを念頭に、モジュール 的性質の高いエレベータの設計業務を扱う注 2)。そして専門職の細分 化が進んでいる米国に着目し、日本のエレベータ専門工事業者によ る設計協力と、米国の Vertical Transportation Consultant(エレ ベータ・コンサルタント、以下VTC とする)による設計業務を調査対 象とする注 ${ }^{3}$ 。

研究の方法として、まず技術的専門性の観点から用語の定義を行 う。次に、エレベータの設計業務についてヒアリングを行い、日本 の設計協力および米国の設計業務に含まれる設計情報作成の責任 ・ 役割を把握する。さらに具体的なプロジェクトを対象として、設計 協力および設計業務によって生成される設計情報を把握する。最後 に、得られた調查結果をもとに日本の専門工事業者による設計協力 と米国の設計専門職による設計業務の差異を把握する。

\section{3 既往研究}

設計協力は、橋梁や水門等の土木プロジェクトを中心に、社会的 問題として認識されている。入札談合事件と設計協力との関係につ いては藤木の研究 ${ }^{4)}$ や、日経コンストラクション誌において複数回 の特集記事がある注4)。建築プロジェクトは土木プロジェクトに比べ、 発注段階で最終成果物を想定することが困難であり、設計や発注の プロセスも異なる。従って、建築プロジェクトにおける設計協力に ついては、土木プロジェクトと個別に調查分析する必要がある。

専門工事業者の企業行動については、元請業者と専門工事業者と

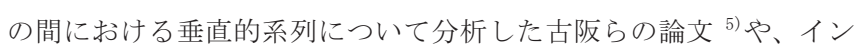
フォーマルかつ自発的協調関係を有寸る日本の建築生産の特質の説 明を試みた長嶋らの論文 ${ }^{6}$ がある。これらは、商習慣に基づく専門 工事業者による設計協力の背景を説明しているものの、設計協力の 詳細を個別に調查し、専門職による設計業務と比較・分析している わけでは無い。

設計協力により作成された設計情報は、役割や責任の所在があい まいになる。Spearin Doctrine 注 5) の見地から、設計専門家各々の 役割・責任について論じたものに平野らの論文 ${ }^{7)}$ がある。本稿はこ のように役割・責任があいまいな日本の設計業務の実情を前提とし ている。

日本の建設産業は、多数の業者によって構成される重層下請構造 をとっている ${ }^{8)}$ 。この様な組織において建築物の施工に関する細か
な技術・技能は、主に専門工事業者が保有している ${ }^{9)}$ とされるフ アサード・エンジニアリングを調查対象としたものに、ヨーロッパ については安藤らの論文 ${ }^{10)}$ 、日本については井上らの論文 ${ }^{11)}$ がある。 これらの論文を今回の調査において参照した。

建築家の職能について欧米の職能に関する概念を明らかにし、日 本の建築士制度との関係を論じた高橋らの論文 ${ }^{12)}$ がある。さらに、 多様化する職能の現状を把握・類型化した古阪・宮井らの論文 ${ }^{13)}, 14$ 、 設計業務の階層構造に着目し、今後成立しうる新職能の可能性を示 唆した金多らの論文 ${ }^{15)}$ がある。本稿で対象としている米国のエレ心゙ ータ・コンサルタントは、モジュール的かつ限定的な業務内容を持 つ、多様化した職能の一つであると言える。

設計協力は、否定的な側面ばかりでなく、肯定的な側面も有する。 デザインの完成度を上げること、物理的な品質を確保すること、工 期・コストを守ることを目的とした設計者と施工者間の伝統的な連 携の手法については、前川國男や村野藤吾の事例を用いて調查した 西野らの一連の論文 ${ }^{16)}$, 17) がある。法制度や分業体制が現在ほど厳 格ではなく、より緩やかな協調関係を実現していた伝統的な方法に よって、発注者、設計者、施工者間の厚き信頼関係と相互依存関係 のもとで、高い品質を実現する建築プロジェクトが実施されてきた ことを示している。

\section{4 用語の定義}

「分業」を「生産過程をいくつかの部門や工程に分け、異なる人々 がこの分割された特殊的部分に専門的に従事すること」とする注5)。

「設計専門職注 6)」を「技術的専門知識を有償の設計業務として提 供する職位、ないしはそのような職位を担当する人」とする。従っ て、建築家/建築士や意匠設計者のみならず、構造設計者や設備設計 者などのエンジニアも「設計専門職」とする。外部専門職（コンサ ルタント）に限定せず、該当する組織設計事務所に所属する意匠設 計者・構造設計者・設備設計者などについても「設計専門職」とす る。「設計専門職」間における分業は、「技術的専門性に基づく分業」 とみなすことができる。

「設計情報作成者」を「設計専門職』以外の設計情報を作成する 者」とする。設計情報は「設計専門職」によってのみ作成されるわ けではなく、一般的に施工者とみなされる総合工事業者・専門工事 業者・材料供給業者らによっても作成される。概念図をFig. 1 に示 す。

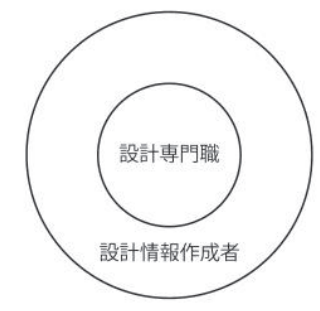

Fig.1 Design Profession and Design Information Creator

「設計協力」を「『設計情報作成者』である専門工事業者等の設計 チームが、技術的専門知識を無償で『設計専門職』に対して提供す ること」とする。「設計協力」では、自社製品に関する技術的専門知 識の提供において、「設計専門職」から「設計情報作成者」に対して 
直接的な対価が支払われない。専門工事業者等へ支払われる報酬は 工事を請け負った場合の材料費と工事費であり、このようなやり方 は材工一括方式と呼ばれている ${ }^{11)}$ 。「設計協力」に関する概念図を Fig. 2 に示す。

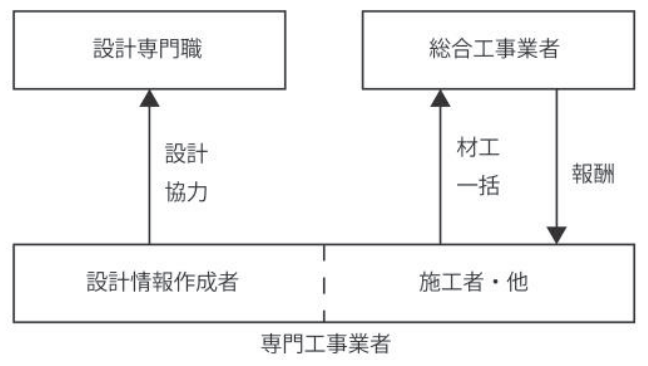

Fig.2 Design Assistance 注 7)

\section{2. エレベータ設計業務における実態調査}

\section{1 概要}

日本のエレベータ業界について概要を記す。昇降機業界の板金部 材調達についての記事（2006 年） ${ }^{18)}$ によると、エレベータ業界は、 上位 3 社が国内シェアの 8 割弱を占めている注 8$)$ 。また日経情報スト ラテジーの記事 (2009 年) ${ }^{19)}$ によると、上位 3 社で市場の 7 割強を 占め、それに 2 社を加えた 5 社で 9 割を超える寡占状態である注9)。 従って、これら上位 5 社を今回の調查対象とする注 10)。また、2014 年度のエレベータの新規設置台数が 25,876 台に対し、エレベータの 改修（完全撤去新設・準撤去新設）は 2, 271 台 ${ }^{20)}$ であるため、新規 設置が主たる調查対象となる。2016 年 7 月と 8 月に、 5 社 13 名に対 してヒアリングを行った。不明点については電子メールで追加調查 を行った。設計協力の概要とともに、各社 2 物件以上のプロジェク 卜事例を入手した。各プロジェクトについて、設計協力により提供 された設計情報量順に並べたものをTable1に示す。

米国の VTC について概要を記す。International Association of Elevator Consultants (IAEC) というエレベータ・コンサルタントの 業界団体があり、米国内で約 90 人、米国外で 3 人が会員登録してい る。正会員は、業務委託契約のもと設計・監理・検查・調查などの 業務を行う。また、製造・販売・施工・維持管理を行うものは、正 会員になることができない ${ }^{21)}$ 。あくまでも設計者・監理者・検査員 として独立して業務委託を受けているため、設計業務を行うVTC は、 設計専門職であるといえる。調査の手順として、まずエレベータ・ メーカーの業務についてヒアリングを行う。2016 年 7 月と 8 月に米 国の設計専門職 (Architect) 5 名に電子メールにてVTCへの業務委託 状況について確認した。次に、IAEC の名簿等に記載されているウェ ブサイトの記載内容の調查により、各 VTC が提供している業務内容 についての整理を行った(Table3)。さらに、設計専門職 (Architect) からの紹介や IAEC のリストに掲載されている 25 人に対して電子メ ールにて調查依頼を行った。 5 人から質疑回答を得ることができ、 うち 4 人からプロジェクト事例を入手した。不明点については電子 メールで追加調查を行った。各プロジェクトの調查結果について、 新設 (New Construction)を Table5 に、改修(Modernization)を Table6 に示寸。

なお日米のエレベータ専門工事業者・メーカーは、ウェブサイト 等で既製品に関する図面や仕様書による設計情報提供を行っている
が、これらは主に中小規模の共同住宅などの建築物に対するエレ心゙ 一タ設置を目的とした設計情報提供であり、既製品の改造は伴わな い。本稿では、こうした既製品に関する設計情報提供は設計協力と はみなしていない注 11$)$ 。ま、受注後のエレベータ専門工事業者に よる設計情報作成は、有償のエレベータ製造・施工と連動している ため、設計協力とはみなしていない。

\section{2 日本の専門工事業者におけるエレベータ設計協力について}

日本におけるエレベータ設計協力について整理する。エレベータ の計画から運営まで、営業・設計・製造・施工・維持管理と多くの 人々が携わるが、全社とも、社内にこれらすべての部門を持つか、 系列会社を有しており、計画から運営まで一貫してサービスを提供 できる体制を整えている。その中で、エレベータの設計プロセスは、 受注前と受注後の 2 段階に分けることができる。受注前には主とし て本社や営業所にて設計情報作成者による営業設計が行われる。受 注後は製品生産を前提として、仕様の確定が主に営業設計主導で行 われた後、工場にて製作図が作成される。受注前の段階では受注は 未確定であり、無償の設計協力が必ずしも受注に結びつく訳ではな い。この受注前と受注後の枠組みは、設計施工分離や設計施工一括 といった発注形態によらないことをヒアリングから確認した。設計 施工一括の場合、設計協力を提供する対象者は、基本設計を行う設 計事務所から実施設計を行う総合工事業者の設計部へと移行する。 また、設計情報作成者による営業設計は、個々の設計専門職に対し てではなく、プロジェクト又は営業担当としている組織設計事務所 や総合工事業者の設計部に対して設計協力を行うことを確認した。

次に、設計協力に含まれる設計情報作成の責任・役割を把握する。 設計専門職とエレベータ専門工事業者間の責任範囲について調査寸 るため、エレベータに関する設計情報が記載された図面や仕様書の 責任の所在についてヒアリングした。設計協力によって作成した図 面や仕様書が設計図書に記載されるときにエレベータ・メーカー名 が記載されるか否かを確認したところ、エレベータ・メーカー名が 記載されることはないとの回答を全社から得た。エレベータに関す る設計情報は、建築確認申請時や発注時に使用されるが、設計専門 職は、エレベータに関する記載事項すべての技術的内容を詳細まで 理解することなく、設計図書を作成する可能性が指摘される。記載 事項に不備があり、その責任の所在を問われる場合、非公式な設計 情報提供である以上、責任は図面枠に名称が記載されている設計専 門職が問われるとの見解を、ヒアリング対象者全員が示していた。

続いて、設計協力により生成される設計情報を把握する。5 社か ら 2 物件以上ずつ具体的なプロジェクトに関する設計情報を収集し た。設計協力の詳細について理解するため、設計協力期間、設計協 力委託時に設計専門職から与えられた設計情報、設計協力内容を調 查項目とした。Table1 に調查結果を示す。まず設計協力により生成 され設計専門職に提供される設計情報は、図面 (平面図・立面図・ 断面図・詳細図など)、仕様書、分析結果（最適な速度の検討・人口 に対する台数設定検討・交通計算など）、デザイン関連（レンダリン グイメージ図作成など)、コスト関連 $($ 新設費・維持管理費算出など) があり、要望に応じて必要な設計情報提供を行っていることが分か った。特に分析と図面・仕様書作成は、平面計画の変更 $\rightarrow$ フア別 滞在人口の変更 $\rightarrow$ エレベータコアの変更 $\rightarrow$ 平面計画の変更とした 
Table1 Design Assistance in J apanese Projects

\begin{tabular}{|c|c|c|c|c|c|c|c|c|c|c|c|c|c|}
\hline \multicolumn{2}{|c|}{ 建物種別 } & $\begin{array}{c}\text { 事務所 } \\
\text { (複合施設) }\end{array}$ & $\begin{array}{c}\text { 事務所 } \\
\text { (複合施設) }\end{array}$ & 病院 & $\begin{array}{c}\text { 事務所 } \\
\text { (複合施設) }\end{array}$ & $\begin{array}{c}\text { 事務所 } \\
\text { (複合施設) }\end{array}$ & $\begin{array}{c}\text { 事務所 } \\
\text { (複合施設) }\end{array}$ & 事務所 & 学校 & 共同住宅 & 共同住宅 & 共同住宅 & 共同住宅 \\
\hline \multicolumn{2}{|c|}{ 着床階 } & 58 & 35 & 17 & 23 & 18 & 12 & 不明 & 不明 & 15 & 10 & 14 & 5 \\
\hline \multicolumn{2}{|c|}{ 設置台数 } & \begin{tabular}{|c|}
21 \\
但し別途 \\
他社納入分有
\end{tabular} & 27 & 10 & 12 & 23 & 5 & 不明 & 不明 & 2 & 不明 & 1 & 1 \\
\hline \multicolumn{2}{|c|}{ 特注品/既成品 } & 特注品 & 特注品 & 特注品 & 特注品 & 特注品 & 特注品 & 特注品 & 既成品 & 既製品 & 既成品 & 既製品 & 既製品 \\
\hline \multicolumn{2}{|c|}{ 新設/改修 } & 新設 & 新設 & 新設 & 新設 & 新設 & 新設 & 新設 & 新設 & 新設 & 改修 & 新設 & 改修 \\
\hline $\begin{array}{c}\text { 設計協力 } \\
\text { 期間 }\end{array}$ & いつから & 基本計画 & 基本計画 & 基本計画 & 基本計画 & 基本設計 & 基本設計 & 基本設計 & 基本設計 & 実施設計 & 基本設計 & 実施設計 & 実施設計 \\
\hline \multicolumn{2}{|c|}{$\begin{array}{l}\text { 設計専門職から } \\
\text { 与えられた情報 }\end{array}$} & $\begin{array}{c}\text { 床面積 } \\
\text { 人員 } \\
\text { 高さ 階数 } \\
\text { サービス条件 }\end{array}$ & $\begin{array}{c}\text { 平面図 } \\
\text { 断面図 } \\
\text { 人口 }\end{array}$ & $\begin{array}{c}\text { 平面図 } \\
\text { 断面図 } \\
\text { 人口 }\end{array}$ & $\begin{array}{c}\text { 敷地図 } \\
\text { 容積 } \\
\text { 建物高さ }\end{array}$ & $\begin{array}{l}\text { 敷地図 } \\
\text { 配置図 } \\
\text { 平面図 } \\
\text { 断面図 }\end{array}$ & $\begin{array}{l}\text { 平面図 } \\
\text { 断面図 }\end{array}$ & $\begin{array}{l}\text { 平面図 } \\
\text { 断面図 }\end{array}$ & $\begin{array}{l}\text { 平面図 } \\
\text { 断面図 }\end{array}$ & $\begin{array}{l}\text { 平面図 } \\
\text { 断面図 }\end{array}$ & $\begin{array}{l}\text { 平面図 } \\
\text { 断面図 }\end{array}$ & $\begin{array}{l}\text { 平面図 } \\
\text { 断面図 }\end{array}$ & $\begin{array}{l}\text { 平面図 } \\
\text { 断面図 }\end{array}$ \\
\hline \multirow{4}{*}{$\begin{array}{l}\text { 設計専門 } \\
\text { 職に提示 } \\
\text { する情報 }\end{array}$} & 図面作成 & 0 & O & 0 & O & 0 & O & O & 0 & 0 & 0 & O & 0 \\
\hline & 仕様書作成 & 0 & 0 & O & $\mathrm{O}$ & O & 0 & 0 & O & 0 & $\mathrm{O}$ & 0 & O \\
\hline & 交通計算 & 0 & O & 0 & O & 0 & O & & & & & & \\
\hline & イメージ図作成 & & 0 & & & & & 0 & & & & & \\
\hline
\end{tabular}

一連の変更と連動しているため、設計協力を通じて絶えず設計情報 を更新していることを確認した。

また設計協力の対象となるエレベータが、軽微な改造を伴う既製 品注 12) または特注品かで、設計協力により提供される設計情報が大 きく異なることが分かる。着床数や設置台数の少ない不確実性の低 い小規模建築物では軽微な改造を伴う既製品が使用される場合が多 く、設計協力期間も短く、設計専門職から提供される設計情報、お よび設計専門職へ提供する設計情報も限定されている。一方、着床 数や設置台数の多い不確実性の高い大規模建築物では、特注品が使 用される場合が多い。プロジェクトの早期から長期間にわたり設計 協力を行う。設計専門職から多種の設計与条件が与えられ、設計協 力として多種の設計情報を作成・提供する。設計情報の提供も多岐 にわたる。特に大規模な事務所ビルの場合、建築物単体というより も都市的な視点で人の動きを予測する必要があるため、基本計画段 階から、高度な設計情報の提供を行っていることを確認した (Table2 参照)。

Table2 Summery of Design Assistance in J apanese Projects

\begin{tabular}{|c|c|c|c|}
\hline エレベータの種類 & 特注品 & 軽微改造を伴う既製品 & 既製品 \\
\hline 設計に関する不確実性 & 高い & 低い & なし \\
\hline 設計協力開始時期 & 基本計画 $\cdot$ 基本設計 & 実施設計 & なし \\
\hline 設計協力完了時期 & 実施設計終了時 & 実施設計終了時 & なし \\
\hline 設計協力期間 & 長い & 短い & なし \\
\hline 設計者から与えられた情報 & 多い & 少ない & なし \\
\hline 設計協力した情報 & 多い & 少ない & なし \\
\hline
\end{tabular}

設計協力により生成される設計情報は、エレベータ専門工事業者 から設計専門職に提供される設計情報だけでなく、設計専門職から エレベータ専門工事業者へと提供される設計情報もある。ヒアリン グにより設計協力を通じて得られた設計情報を製品開発に役立てて いることを、全社から確認した。通常、エレベータ専門工事業者の 営業設計を行っている設計情報作成者が、発注者のニーズを直接聞 く機会はない。特に特注エレベータの設計協力を通じて、設計専門 職から既製品では対応することのできない発注者の個別のニーズを くみ取っていると言える。例えば、タッチセンサーではなく赤外線 センサーによる挟まり防止機能、かご内 AED 設置対応により各階か らのアクセスを容易にする機能、可変速機構により運行スピードを
上げる機能、ダブルデッキエレベータにおける階間調整機能などは、 すべて設計専門職側から要請を受け、製品開発につながった事例と して確認した。

ちなみに製品開発につながる設計情報を、自社または系列会社の 維持管理部門より入手する場合もある。例えば、(1)音や摇れといっ た利用者からのフィードバックが製品の向上につながること、(2)建 物とエレベータかご間の寸きまからの私物落下防止対策がすきまレ ス機能開発につながったこと、(3)地震後の仮復旧時に通常時と同等 使用可能な長時間作動バッテリーの追加設置をするようになったこ と、などの事例を確認した。発注者・設計者のみならず、運用者・ 利用者からも、専門工事業者に対して設計情報が供給されていると 言える主 13)

\section{3 米国の設計専門職 (VTC)によるエレベータ設計業務について}

米国におけるエレベータ設計業務について整理する。まず米国の 大手エレベータ・メーカー4 社に、(1)一般通常業務内容について(2) 特注品対応の有無について(3)VTC との業務の進め方について電子メ ールにて質問したところ、1 社から回答を得た。(1)ついては、営 業・設計・製造・施工・維持管理まで広く請け負うことが可能であ ること注 ${ }^{14)}$ 、(2)については、既製品に関する設計情報提供は無償だ が特注品の図面作成・仕様書作成・分析等に関する設計情報提供は 有償であること、(3)については、VTC の作成する図面や仕様書に従 って製品を提供すること、およびエレベータ・メーカー自ら VTC を 雇用し設計情報提供の要望に対応寸る場合もあることを確認した。

また設計専門職 (Architect) 5 名に電子メールにてVTCへの業務委 託状況について確認した。(1)どのような建築プロジェクトの場合 VTC に業務委託寸るのか、(2)VTC に業務委託しない場合エレベータに 関する設計情報はどのように入手するのか、という質疑を行った。 (1)については、特注品を用いる場合・4 基以上設置する場合・高層 建築物を設計する場合 VTC に業務委託を行う、(2)については、エレ ベータ・メーカーのウェブサイトや取扱店から既製品の図面や仕様 書を入手するという回答を得た注 ${ }^{15)}$ 。既製品のエレベータを設置す る小規模なプロジェクトでは、エレベータ・メーカーから設計情報 を直接得る点では、日本と米国に違いはないことを確認した。

次に、設計業務に含まれる設計情報作成の責任・役割を把握する。 
Table3 Services of Vertical Transportation Consultants

\begin{tabular}{|c|c|c|c|c|c|c|c|c|c|c|c|c|c|}
\hline \multirow{2}{*}{ Firm } & \multirow{2}{*}{$\begin{array}{c}\text { Location of } \\
\text { HQ }\end{array}$} & \multicolumn{4}{|c|}{ New Costrcution } & \multicolumn{4}{|c|}{ Modernization } & \multirow{2}{*}{$\begin{array}{c}\text { Maintenance } \\
\text { Review }\end{array}$} & \multirow{2}{*}{ Assessment } & \multirow{2}{*}{ Litigation } & \multirow{2}{*}{ Inspection } \\
\hline & & Specificaiton & Drawing & Analysis & PM Related & Specificaiton & Drawing & Analysis & PM Related & & & & \\
\hline 1 & NJ & 0 & 0 & 0 & 0 & 0 & 0 & 0 & 0 & 0 & 0 & 0 & 0 \\
\hline 2 & $\mathrm{CO}$ & $\mathrm{O}$ & $\mathrm{O}$ & 0 & 0 & 0 & 0 & 0 & 0 & 0 & 0 & - & 0 \\
\hline 3 & NY & $\mathrm{O}$ & 0 & 0 & 0 & 0 & 0 & 0 & 0 & 0 & 0 & 0 & - \\
\hline 4 & MD & O & 0 & 0 & 0 & 0 & 0 & 0 & 0 & 0 & 0 & - & 0 \\
\hline 5 & MO & 0 & 0 & 0 & 0 & 0 & 0 & 0 & 0 & 0 & 0 & - & 0 \\
\hline 6 & $\mathrm{NH}$ & 0 & 0 & 0 & 0 & 0 & 0 & 0 & 0 & 0 & 0 & - & 0 \\
\hline 7 & NY & 0 & 0 & 0 & 0 & 0 & 0 & 0 & 0 & 0 & 0 & - & 0 \\
\hline 8 & $\mathrm{CO}$ & 0 & - & 0 & 0 & 0 & 0 & 0 & 0 & 0 & 0 & 0 & 0 \\
\hline 9 & $\mathrm{MD}$ & 0 & 0 & 0 & 0 & 0 & 0 & 0 & 0 & 0 & 0 & - & - \\
\hline 10 & CA & 0 & 0 & 0 & 0 & 0 & - & 0 & 0 & 0 & 0 & - & 0 \\
\hline 11 & CA & $\mathrm{O}$ & 0 & 0 & 0 & 0 & 0 & 0 & 0 & 0 & 0 & - & - \\
\hline 12 & $\mathrm{NY}$ & 0 & 0 & 0 & 0 & 0 & - & 0 & 0 & 0 & 0 & - & - \\
\hline 13 & $\mathrm{MN}$ & 0 & - & 0 & 0 & 0 & - & 0 & 0 & 0 & 0 & - & 0 \\
\hline 14 & $\mathrm{NY}$ & - & - & - & - & 0 & 0 & 0 & 0 & 0 & 0 & 0 & 0 \\
\hline 15 & CA & 0 & 0 & 0 & 0 & 0 & 0 & 0 & 0 & - & - & - & - \\
\hline 16 & IL & 0 & - & 0 & - & 0 & - & 0 & 0 & 0 & 0 & - & 0 \\
\hline 17 & TX & - & - & - & - & 0 & - & 0 & 0 & 0 & 0 & 0 & 0 \\
\hline 18 & IN & 0 & - & - & 0 & 0 & - & - & 0 & 0 & - & 0 & 0 \\
\hline 19 & $\mathrm{NY}$ & 0 & 0 & 0 & 0 & - & - & $\bar{O}$ & - & 0 & - & - & - \\
\hline 20 & $\mathrm{NY}$ & 0 & - & - & - & 0 & - & - & - & 0 & 0 & 0 & 0 \\
\hline 21 & CT & - & - & - & 0 & 0 & - & - & 0 & 0 & 0 & - & 0 \\
\hline 22 & $\mathrm{MD}$ & - & - & - & - & 0 & - & $\bar{O}$ & 0 & 0 & 0 & - & 0 \\
\hline 23 & $\mathrm{NY}$ & - & - & - & - & 0 & - & - & 0 & 0 & - & 0 & 0 \\
\hline 24 & IN & - & - & - & - & 0 & - & - & - & - & 0 & 0 & 0 \\
\hline 25 & $\mathrm{NY}$ & - & - & - & - & - & - & - & - & 0 & - & 0 & 0 \\
\hline 26 & $\mathrm{FL}$ & - & - & - & - & 0 & - & - & 0 & 0 & - & - & - \\
\hline 27 & CA & - & - & - & - & - & - & - & - & - & - & 0 & - \\
\hline
\end{tabular}

まずVTC を対象として図面や仕様書の作成状況について電子メール にて質問した。(1)成果物として提出する図面や仕様書に対してサイ ンやスタンプをするか、さらに(2)作成した図面や仕様書が設計図書 に記載されるときにVTCの会社名が記載されるか否かを確認した。 (1)に対しては、成果物にはサインをしないと回答した人が過半であ ったが、サインをすると答えた人も 1 名いた。(2)に対しても、設計 図書に対してVTC の会社名は記載されないと 1 名以外の全員から回 答を得た。VTC が作成したエレベータに関する図面や仕様書の記載 事項に不備がある場合、その責任の所在は図面や仕様書の作成者で あるVTCにある。しかし、その設計情報が組み込まれて作成された 設計図書に対する主たる責任は設計統括責任者である設計専門職 (Architect)にあるため、それらの設計図書に対してVTC の会社名は 記載されない旨、回答者から追加説明を受けた。VTC は、プロジェ クト関係者すべてに対して責任を明確に示しているわけではないも のの、少なくとも業務委託者である設計専門職(Architect) とVTC との間では、設計専門職として責任の所在を明確にしているといえ る。

続いて設計業務により生成され、設計専門職 (VTC) から設計専門職 (Architect) に提供される設計情報として、VTCの一般的業務内容を 調查した。IAECの正会員のコンサルタントのリストのうち、業務内 容が記述してあるウェブサイト 25 件と、設計専門職 (Architect) か ら推薦のあったVTC コンサルタントのウェブサイト 2 件、計 27 件を 調査した。記載されている業務の多い順に並べた調査結果を示す (Table3) 注16)。大きくは New Construction (新設) と Modernization (改修) といったエレベータ設置用の設計業務と、Maintenance Review(発注者と維持管理業者との契約内容やサービス状沉の精査)、 Assessment（エレベータ作動状況精查、建物売買用評価業務）、 Litigation（訴訟用資料收集）、Inspection（法適合確認）といった エレベータ自体の調查・検查業務に区分できる。調查対象とした 27 件のウェブサイトでの記載内容を比較すると、エレベータ設置用の
設計業務が主たるもの、エレベータ自体の調査・検查業務が主たる もの、およびその両方を行うものがあった。エレベータ設置用の設 計業務では、Specification（仕様書作成）についてのみ記述し、 Drawing（図面作成）やAnalysis（交通計算など）については記述 されていない事例が多々見受けられた。発注後に専門工事業者が決 定されるまでは、仕様書に記載された内容と、既製品の図面を前提 に、設計が進められていくと予想される。また、New Construction (新設) と Modernization（改修）を比較すると、改修を主として 業務の詳細を記載しているウェブサイトが大多数であることを確認 した。既存建築物を維持管理しながら長期間にわたり使用していく 米国の特徴がよく表れていると考えられる。

さらに調查協力者であるVTC5 名に対して、各個人の経歴等につい て電子メールにて質問した (Table4)。もともとエレベータ・メーカ 一や組織設計事務所内で技術者として勤務し、エレベータの設計に 関するノウハウを吸収した後、独立してコンサルタント業を始めて いる者を複数確認した。構造設計者や設備 $(\mathrm{M}$ : 機械、 $\mathrm{E}$ : 電気、 $\mathrm{P}$ : 給 排水衛生）設計者と同様に、設計専門職として扱われているようで あるものの、エレベータ設計専門の免許保有が必須でないことも分 かった。ヒアリングにより、エレベータの販売・施工業務を数年行 っただけでVTC として独立する者がいるものの、こうしたコンサル タントは、エレベータの新設が伴う業務は行わない者もいるとの回 答を得た。

続いて、調查協力者であるVTC4 人から具体的なプロジェクトの設 計情報を収集した。新設 (New Construction)をTable5 に、改修 (Modernization)をTable6 に示す注17)。図面が伴わず仕様書のみが 成果物として提出されているプロジェクトが一定数存在することを 確認した。また、完成時のレンダリングイメージ作成は、どの VTC も行っていなかった。 
Table4 Vertical Transportation Consultants 注 18)

\begin{tabular}{|c|c|c|c|c|c|}
\hline コンサルタント & A & $B$ & $\mathrm{C}$ & $\mathrm{D}$ & $E$ \\
\hline IAECのメンバー & no & no & yes & yes & yes \\
\hline 保有ライセンス & $n / a$ & $\mathrm{n} / \mathrm{a}$ & $\begin{array}{l}\text { Qualified Elevator } \\
\text { Inspector(QEI), } \\
\text { Qualified Elevator } \\
\text { Consultant(QEC) }\end{array}$ & Qualified Elevator Inspector(QEI) & Qualified Elevator Inspector(QEI) \\
\hline $\begin{array}{c}\text { 新設・改修プロジエ } \\
\text { クトの割合 }\end{array}$ & $\mathrm{n} / \mathrm{a}$ & 新設70\% : 改修30\% & 新設10\% : 改修90\% & 新設55\% : 改修45\% & 新設15-20\% : 改修80-85\% \\
\hline $\begin{array}{c}\begin{array}{c}\text { 社内の } \\
\text { コンサルタント数 }\end{array} \\
\end{array}$ & $\mathrm{n} / \mathrm{a}$ & 7名 & 2名 & 150名 & 15名 \\
\hline 経歴 & $\begin{array}{l}\text { エレベータ会社勤務 } \\
\text { (技術営業) } \\
\text { エレベータ会社勤務 } \\
\text { (改修部門マネージャ) } \\
\text { 設備設計事務所勤務 } \\
\text { (エレベータ設計部長) } \\
\text { エレベータ会社勤務 } \\
\text { (技術部部長) } \\
\text { 2000年VTC設立 }\end{array}$ & \begin{tabular}{|} 
エレベータ会社勤務 \\
（機械技術者） \\
組織設計事務所勤務 \\
（エレベータ設計） \\
1986年VTC設立
\end{tabular} & \begin{tabular}{|l} 
エレベータ会社勤務 \\
（調査技師） \\
エレベータ会社勤務 \\
（改修工事専門技術者） \\
1991年VTC設立
\end{tabular} & $\begin{array}{l}\text { 建築学部卒業後 } \\
\text { VTC勤務 } \\
\text { 海外部門担当副社長 }\end{array}$ & \begin{tabular}{|l} 
エレベータ会社勤務 \\
1986年VTC設立
\end{tabular} \\
\hline $\begin{array}{c}\text { 最新の技術的知識を } \\
\text { どのようにして } \\
\text { 入手するか }\end{array}$ & $\begin{array}{l}\text { エレベータ会社勤務時代のネット } \\
\text { ワークを現在でも有している }\end{array}$ & $\begin{array}{l}\text { 5大エレベータ・メーカー(KONE, } \\
\text { Mitsubishi, Otis, Schindler, } \\
\text { ThyssenKrupp)のエンジニアと、 } \\
\text { 年に数回ずつ話して情報を得る }\end{array}$ & $\begin{array}{l}\text { セミナー参加、工場見学、エレベー } \\
\text { タのコンベンション参加、独学 }\end{array}$ & $\begin{array}{l}\text { 各エレベータ・メーカーの主任エン } \\
\text { ジニアに適宜連絡をして、最新の技 } \\
\text { 術的動向について聞く }\end{array}$ & セミナーに参加する \\
\hline BIM対策について & $\mathrm{n} / \mathrm{a}$ & \begin{tabular}{|l|} 
BIM対応した詳細な設計情報を提供 \\
すると、1社独占の情報となるた \\
め、意図的にAutoCadの2次元情報 \\
を提供している。
\end{tabular} & 必要な場合、他社に業務委託する & $\mathrm{n} / \mathrm{a}$ & $\mathrm{n} / \mathrm{a}$ \\
\hline
\end{tabular}

Table5 Consultation Service in US Projects: New Construction

\begin{tabular}{|c|c|c|c|c|c|c|c|c|c|c|c|}
\hline \multirow{2}{*}{\multicolumn{2}{|c|}{$\begin{array}{c}\text { Consultant } \\
\text { Building Type }\end{array}$}} & \multicolumn{3}{|c|}{ A } & \multicolumn{3}{|c|}{ B } & \multirow{2}{*}{$\begin{array}{c}\text { C } \\
\text { Institututional }\end{array}$} & \multicolumn{3}{|c|}{ D } \\
\hline & & Hotel / Office & Residential & Office & Hotel / Office & Office / Residential & Retail & & Mixed Use & Office & Mixed Use \\
\hline \multicolumn{2}{|c|}{ Stories } & 123 & 119 & $n / a$ & 128 & 167 & 2 & 12 & 162 & 80 & 55 \\
\hline \multicolumn{2}{|c|}{ Number of Elevators } & 87 & 12 & $n / a$ & 105 & 59 & 1 & 9 & 53 & 68 & 41 \\
\hline \multirow{2}{*}{$\begin{array}{c}\text { Consultation } \\
\text { service }\end{array}$} & Start & Concept & Concept & Concept & Concept & $\begin{array}{c}\text { Design } \\
\text { Development }\end{array}$ & Concept & $\begin{array}{c}\text { Design } \\
\text { Development }\end{array}$ & Concept & Concept & Concept \\
\hline & End & $\begin{array}{c}\text { Construction } \\
\text { Administration }\end{array}$ & $\begin{array}{c}\text { Construction } \\
\text { Administration }\end{array}$ & $\begin{array}{c}\text { Construction } \\
\text { Administration }\end{array}$ & $\begin{array}{c}\text { Construction } \\
\text { Administration }\end{array}$ & $\begin{array}{c}\text { Construction } \\
\text { Administration }\end{array}$ & $\begin{array}{c}\text { Construction } \\
\text { Administration }\end{array}$ & $\begin{array}{c}\text { Construction } \\
\text { Document }\end{array}$ & $\begin{array}{c}\text { Construction } \\
\text { Administration }\end{array}$ & $\begin{array}{c}\text { Construction } \\
\text { Administration }\end{array}$ & $\begin{array}{c}\text { Construction } \\
\text { Administration }\end{array}$ \\
\hline \multicolumn{2}{|c|}{ Given Information } & $n / a$ & $n / a$ & $n / a$ & General Massing & $\begin{array}{c}\text { Partial DD } \\
\text { drawings, outline } \\
\text { specifications, } \\
\text { elevator studies }\end{array}$ & $\begin{array}{l}\text { General program, } \\
\text { design intent for } \\
\text { the store }\end{array}$ & $\begin{array}{c}\text { Number of } \\
\text { floors/expected } \\
\text { population/use. } \\
\text { Hoistways are } \\
\text { spec'd and } \\
\text { designed by our } \\
\text { firm prior to } \\
\text { architect final }\end{array}$ & $\begin{array}{c}\text { the initial concept } \\
\text { drawings and } \\
\text { design criteria }\end{array}$ & $\begin{array}{c}\text { the initial concept } \\
\text { drawings and } \\
\text { design criteria }\end{array}$ & $\begin{array}{l}\text { the initial concept } \\
\text { drawings and } \\
\text { design criteria }\end{array}$ \\
\hline \multirow{6}{*}{$\begin{array}{l}\text { Submitted } \\
\text { Information }\end{array}$} & Drawing & O & 0 & $\mathrm{O}$ & & & 0 & 0 & O & 0 & 0 \\
\hline & Specification & 0 & 0 & 0 & 0 & 0 & 0 & 0 & 0 & 0 & 0 \\
\hline & Analysis & 0 & 0 & 0 & 0 & & & 0 & 0 & 0 & 0 \\
\hline & Rendering & & & & & & & & & & \\
\hline & Cost Estimation & & & & & & & 0 & 0 & 0 & 0 \\
\hline & PM Related & 0 & 0 & & & 0 & & & 0 & 0 & 0 \\
\hline
\end{tabular}

Table6 Consultation Service in US Projects: Modernization

\begin{tabular}{|c|c|c|c|c|c|}
\hline \multirow{2}{*}{\multicolumn{2}{|c|}{$\begin{array}{c}\text { Consultant } \\
\text { Building Type }\end{array}$}} & c & \multicolumn{3}{|c|}{ D } \\
\hline & & Institututional & Office & Office & Office \\
\hline \multicolumn{2}{|c|}{ Stories } & 9 & 108 & 46 & 40 \\
\hline \multicolumn{2}{|c|}{ Number of Elevators } & 4 & 104 & 20 & 13 \\
\hline \multirow[b]{2}{*}{$\begin{array}{l}\text { Consultation } \\
\text { service }\end{array}$} & Start & Concept & Concept & Concept & Concept \\
\hline & End & $\begin{array}{l}\text { Construction } \\
\text { Administration }\end{array}$ & $\begin{array}{l}\text { Construction } \\
\text { Administration }\end{array}$ & $\begin{array}{l}\text { Construction } \\
\text { Administration }\end{array}$ & $\begin{array}{l}\text { Construction } \\
\text { Administration }\end{array}$ \\
\hline \multicolumn{2}{|c|}{ Given Information } & $\begin{array}{c}\text { Number of } \\
\text { floors/population/u } \\
\text { se, hoistway } \\
\text { dimension, } \\
\text { current } \\
\text { equipment } \\
\text { installed }\end{array}$ & $\begin{array}{c}\text { the initial concept } \\
\text { drawings and } \\
\text { design criteria }\end{array}$ & $\begin{array}{c}\text { the initial concept } \\
\text { drawings and } \\
\text { design criteria }\end{array}$ & $\begin{array}{l}\text { the initial concept } \\
\text { drawings and } \\
\text { design criteria }\end{array}$ \\
\hline \multirow{6}{*}{$\begin{array}{l}\text { Submitted } \\
\text { Information }\end{array}$} & Drawing & o & & & \\
\hline & Specification & 0 & 0 & o & 0 \\
\hline & Analysis & & 0 & 0 & O \\
\hline & Rendering & & & & \\
\hline & Cost Estimation & 0 & 0 & & 0 \\
\hline & PM Related & 0 & 0 & 0 & 0 \\
\hline
\end{tabular}


さらに、設計業務により生成される設計情報が、設計専門職 (Architect)から設計専門職 (VTC) を経て施工者（エレベータ・メー カー) へと提供されているかについて確認する。設計専門職 (VTC) と施工者 (エレベータ・メーカー) 間の設計情報共有の点から、VTC に対して最新の技術的知識の入手方法について質問したところ、エ レベータ・メーカー勤務時点での技術的知識やネットワークを用い つつも、コンベンションに参加し、エレベータ・メーカーのエンジ ニアに定期的に接触して設計情報を得ることが一般的であるとの回 答を複数得た。可能な限り最新の設計情報を得るよう努力している ものの、日本のように社内の別部門として緊密に連携している訳で はない。また、IAECのウェブサイトによると、VTC は、エレベータ の製造・販売・施工・維持管理から独立した存在として、コンサル タントとして設計情報作成や第三者として調査・検査することを求 められる。この点からも、エレベータに関する設計情報と製造・施 工情報との間には明確な境界があり、日本のように緊密に連携して いないと言える。

\section{4 日本の専門エ事業者による設計協力と米国の設計専門職によ る設計業務の差異について}

く日米間で違いがみられなかった内容 $>$

a. 既製品を使う場合、設計専門職はエレベータ・メーカーが提供 するカタログや標準的な罒面、仕様書を参照して基本設計・実 施設計を進める。

b. 特注品を使う場合、設計専門職は基本計画・基本設計の段階か ら、設計協力依頼または設計業務委託を行い、ともにエレベー タの設計を進める。

c. 専門工事業者による設計協力やVTC による設計業務では、 Specification（仕様書作成）、Drawing（図面作成）、Analysis (交通計算他)、Cost Evaluation（コスト算定）の業務を行う。

＜日米間で違いが見られた内容 $>$

a. 米国では、Maintenance Review（発注者と維持管理業者との契 約内容やサービス状況の精査)、Assessment（エレベータ運用 状況精査、売買用適正評価も含む)、Litigation（訴訟時の法 的証拠収集）、Inspection（法適合確認）といったエレベータ 調査・検査業務や、エレベータの設置に関する PM 的業務（発 注書作成・見積りチェック・施工監理など）が、第三者的な立 場の業務として確立している。

b. 米国ではエレベータの改修プロジェクトが多く存在し、VTCの 業務対象となっている。

c. 日本では、専門工事業者内に、設計情報作成者とエレベータの 製作者・施工者が存在し、設計情報のやり取りが行われている が、米国では、VTC とエレベータ・メーカーが別組織となって いるため、日本ほど密に設計情報のやり取りが行われていない。

日本の設計協力において、設計専門職の上流に位置する発注者の 存在は、設計情報の流れと報酬・業務委託料の流れに影響を与えて いる。設計専門職である意匠設計者が取りまとめた設計情報は、設 計業務委託契約の成果物として発注者に提出される。発注者は建築 物の工事発注を通じて、その設計情報を総合工事業者さらには専門 工事業者へと伝達する。一方で、設計協力として非公式な設計情報
の伝達が、設計専門職と専門工事業者内の設計情報作成者との間で 双方向に行われる。結果、設計専門職は無償で設計情報を得ると同 時に、専門工事業者は設計専門職やその先の発注者からのインプッ 卜を積極的に取り入れることができる。このように日本の商慣習に 根差した枠組みの中で、建設業界内で設計情報が循環していること を示している。Fig. 1 を、発注者も含めて加筆修正した図を Fig. 3 に提示する。

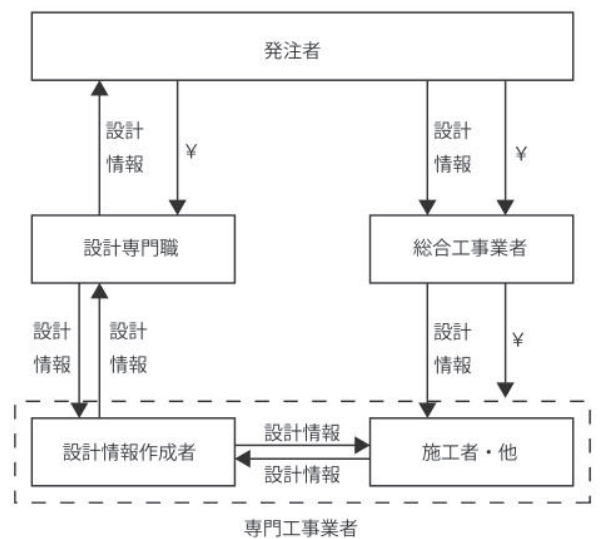

Fig.3 Design Assistance and Design Information Network in J apan

比較のため設計業務の概念図をFig. 4 に提示する。米国の設計業 務において、設計に関する業務委託料は設計関係者に支払われ対価 としての設計情報（設計図書）が納品される。施工に関する報酬は 施工関係者に支払われ、提供した設計情報（設計図書）に適合した 建築物が引き渡される。VTC は設計専門職として、専門工事業者で あるエレベータ・メーカーとは独立した第三者性を確立している。 一方で、施工に関する情報をどのように絶えず更新していくかは米 国のVTC の課題であるといえる。

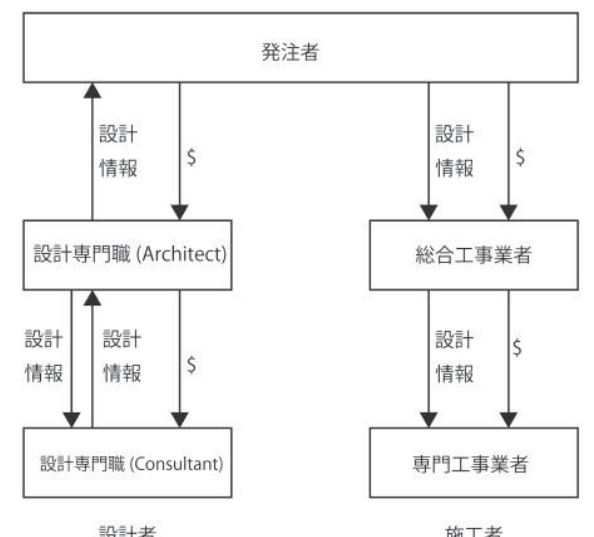

Fig.4 Separation of Design and Construction in US ${ }^{\text {ì }}{ }^{19}$

\section{3. 結語}

本稿は、調查対象をエレベータの設計協力としたうえで、(1)設計 協力に含まれる設計情報作成の責任・役割の把握、(2)設計協力によ り生成された設計情報の把握、(3)日本の専門工事業者による設計協 力と米国の設計専門職による設計業務の差異の把握をした。特に VTC に対するヒアリングは限定された調查対象者から得られた情報 であるためVTC の全体像を示しているとは言えないが、VTC の一般 
的業務内容（Table3）と併せて分析することによって、ある一定の 傾向を把握することができたと考えている。日本の専門工事業者に よる設計協力について以下の知見が得られた。

(1)設計協力に含まれる設計情報作成の責任・役割

1. 図面・仕様書・分析結果等を無償で提供する。

2. 提供する図面・仕様書・分析結果等に対して、設計情報作成 者から発注者に対して直接責任は発生しない。そのため設計 専門職と設計情報作成者との間において、発注者に対する設 計情報の責任の所在が不明確になることがある注 20)。

(2)設計協力により生成された設計情報

1. 専門工事業者の設計情報作成者が設計専門職に提供する設 計情報（図面、仕様書、分析結果、デザイン・コスト関連）

2. 専門工事業者の設計情報作成者が設計専門職から提供を受 ける設計情報（発注者のニーズ）

(3)日本の専門工事業者による設計協力と米国の設計専門職による設 計業務の差異

1. 米国では、Maintenance Review ・Assessment • Litigation・ Inspection といったエレベータ調査・検查業務や、エレベ 一タの設置に関するPM 的業務として確立している。

2. 米国ではエレベータの改修プロジェクトが多く存在し、VTC の業務対象となっている。

3. 米国では、VTC とエレベータ・メーカーが別組織となってい るため、日本ほど密に設計情報のやり取りが行われていない。

\section{4. 今後の課題}

本研究では、専門工事業者の職種をエレベータに特化して調査を 行った。限定された職種のみ扱っているため、専門工事業者による 設計協力全てが、本研究と同じ結果になるとは限らない。今後、ほ かの職種による設計協力についても調査する必要がある。

今回の米国の VTC に対する調查は、電子メールによる調査のため、 調查協力者数や調查内容についてもある程度限定的なものになった。 米国において、エレベータ設計情報作成者 (VTC) とエレベータの製作 者・施工者が別組織となることによる問題点については、まだ調查 が不十分である。今後、対面インタビューの機会を持つなどして継 続的にフォローし、調査内容を補完・修正していきたい。

今後、日本国内にて、さまざまな分野での設計協力が行われると 考えられる。それらへの調查研究も行い、設計協力の全体像を明ら かにするとともに、米国におけるVTC のようなコンサルタント業へ 変貌するのか、我が国特有の仕組みとして成長していくのか、それ らついての調查・研究を引き続き進めていきたい。

\section{謝辞}

本研究にあたり、日本のエレベータ・メーカーの営業・技術者の 方々や、米国のVertical Transportation Consultants やArchitects の方々から、多岐にわたりご協力いただきました。この場を借りて 厚く御礼申し上げます。

注

注1）専門工事業者には、労務供給中心の業者と材工一括により受注する 業者があると言われている。（古阪秀三編，建築生産ハンドブック， p. 16）本稿では、労務供給型ではなく、材工一括型の専門工事業者
による設計協力を前提とする。

注2）エレベータにモジュラー化の傾向が起こりやすく、専門工事業者側 に技術知識が偏在することが指摘されている（吉田敏，建築におけ る技術知識の偏在に関する考察, 日本建築学会、建築社会システム 委員会, 第 28 回建築生産シンポジウム, 2012）。一方で、一部には エレベータをビルディング・システムの一部として防犯システムや ファシリティマネジメントシステムと統合して企画・設計する先進 的な試みが進められている。

注3）独立性の高い設計業務の場合、設計業務内容が特定し易く、責任・ 役割が判別しやすいと考える。また縦動線の計画は、高層建築物の 建築計画の中で重要な位置を占めるため、エレベータに関する技術 的知識は、設計の比較的早い段階で必要とされる可能性が高い。

注4）日経コンストラクションにおける特集については以下のものがある。 「脱・裏設計」の波紋 (2006.07.28) 、発注者の不作為：非公式な設 計協力の存在を黙認 $(2007.7 .27)$ 、脱談合後の針路：裹設計が消滅 一設計付きの工事発注が増える（2008.1.11）、現場を摇るがす「設 計の劣化」: 裏設計でゆがめられた設計・施工の分離 (2008.05.09)

注5） 1918 年の Spearin Doctrine(1918 年)とは「工事契約において、発 注者が提供した図面・仕様書の正確さについては、発注者が黙約的 に保障 impliedly warrant し、その誤り等に起因する損害について、 請負者は免責される」というものであり、政府担当官や設計専門家 が工事の計画及び運営に必要な技術や知識を独占した時代の判例で あると言える。

注6）本稿では、建築家/建築士の代わりに、設計専門職という用語を用い る。「わが国では建築家という言葉が不明確であり、建築家の資格 についてもまだ社会的に認知されたものになっていない。これは、 設計という業務が欧米から入ってきてわが国に定着するまでの経緯、 建築教育のあり方、設計者を規定する法律（建築士法上の建築士）、 設計者と施工者の業務分担のわが国の歴史などに起因している。」 (大武通伯: 設計者という言葉, 古阪秀三編, 建築生産ハンドブック, 朝倉書店, pp. 349-350, 2007)

注7）井上朝雄, 松村秀一, 清家剛：日本におけるファサード・エンジニ アリングの成立要件, 第 18 回建築生産シンポジウム, pp. 139-144, 2002 における図 1 「日本の外壁生産組織の特徵」を加筆修正した。 また米国では、費用発生の有無によらず、専門工事業者による設計 情報の提供をDesign Assist と呼ぶことがある。

注8）国立国会図書館，C2007T0725,エレベータのシェア・市場規模を調べ たいより引用

注9）内古田, 金岡, 賀川, 木村 : エレベータ専業メーカーのケーススタ ディレポート (http://www. osaka-ue. ac. jp/zemi/honma/seminar/ エレベータ専業メーカーのケースステディレポート.pdf）より引用

注10）各社のシェアについては、5社すべてから返答を得ることができな かったが、エレベータ業界として、シェアについての返答をしない 取り決めになっていることをヒアリングから確認した。

注11） ウェブサイト上での情報提供に関寸る詳細は、コンピュータシステ ム上での情報提供となるため、今回のヒアリングで確認することが できなかった。

注12）建築プロジェクトは基本的に一品受注生産であるため、同じ既製品 を利用したとしても、必ずしも製品の設置状況は同じではないため、 既製品であっても軽微な改造が伴う場合がある。そのため、特注品 であるか軽微な改造を伴う既製品であるかについては、二元的に分 類できるのではなく、特注の程度によって段階的に分類できると考 える。

注13）調査対象とした 5 社のうち、3 社は総合電機メーカーの一部門とし てエレベータ等を扱う専門工事業者であり、残りの 2 社はエレベー 夕専門の専門工事業者である。前者は、総合電機メーカーの強みを 生かし、系列会社の開発した技術をエレベータに取り入れる試みを 積極的に行っている。一方後者は、エレベータ専門工事業者である ことを前面に出しつつ、専門の人材を効率的に配置しながら、販売 網を世界的に広げている傾向があることをヒアリングによって確認 した。

注14）計画から運営まで一貫してサービスを提供できる体制を整えている エレベータ・メーカーは皆無で、通常別々の会社組織が行っている ことを、VTCに対する電子メールによる追加質疑によって確認した。 注15）仕様書に、資料を入手したメーカー名を明記したうえで、「同等品」 と併記、または他社名をその下に記載する場合がある。 
注16）VTCによっては、全米や世界各地にネットワークを持つものもあれ ば、地元密着型で特に New Construction（新設）を行わないものも ある。VTCは、高層の建物が集積している東海岸の New York 州近辺 および、西海岸California 州に多く立地しているものの、概して一 極集中ではなく全米に分散して立地している。

注17）まず設計対象となるエレベータは、全て特注品であった。着床数や 設置台数の少ない小規模建築物用に既製品を設置する場合、必ずし もVTCに業務委託する必要はない。特注品が前提となる場合、着床 数や設置台数の多い不確実性の高い大規模建築物であるため、プロ ジェクトのコンセプト段階から監理段階まで長期間にわたり業務を 行っていることが分かる。

注18）VTCとして積極的に詳細な BIM データを作成・提供している事例は 一件のみであった。BIMによる設計情報提供は、まだ一般的ではな いと思われる。

注19）施工者側の設計情報及び報酬の流れは、発注形態によって異なる。 本稿では、設計協力の流れと比較するために、便宜的に、総合工事 業者を経由して報酬が支払われるとする。

注20）提供する図面・仕様書・分析結果について、設計情報作成者は提供 先の設計専門職に対してその内容については責任を持ち、設計専門 職は発注者に対して、それらの内容にかかわる責任を持つ。そして、 設計情報作成者が設計情報を作成する基となる設計情報の内容につ いては提供する設計専門職が責任を持つことが原則である。一方、 これらの内容に係わる原則的な責任の範囲について、そのやりとり の中で、不明確になることも少なくない実態があり、それがあいま いな設計業務の実情とされている。

\section{参考文献}

1) Ogasawara, M., Yoshida, S. and Yashiro, T.: Comparative Study of the Task Distribution in Architectural Design Firm: Japan and US case studies, Journal of Architecture and Planning (Transactions of AIJ), Vol.81, No.722, pp.991-999, 2016.4 (in Japanese) 小笠原正豊，吉田敏，野城智也：組織設計事務所における設計分業体 制に関する基本的考察, 日本建築学会計画系論文集, 第 81 巻, 第 722 号, pp.991-999, 2016.4

2) Minemasa, K. and Furusaka, S.: Research on the method with the cooperative business in the building project: About building of the structure of production stage architect and contractor's creative cooperation, Symposium on building construction and management of projects (Transactions of AIJ), 16 ${ }^{\text {th }}$, pp.219-226, 2000 (in Japanese)

峰政克義, 古阪秀三 : 建築プロジェクトにおける協調的業務のあり方 に関する研究, 日本建築学会建築経済委員会, 第 16 回建築生産シンポ ジウム, pp.219-226, 2000

3) Minemasa, K. and Furusaka, S.: The rationalization of the building industry using concurrent engineering/design by the cooperation between designers and contractors, Symposium on building construction and management of projects (Transactions of AIJ), 17th, pp.325-332, 2001 (in Japanese)

峰政克義, 古阪秀三：設計者と生産者の協調型設計と建築産業の合理 化, 日本建築学会建築経済委員会, 第 17 回建築生産シンポジウム, pp.325-332, 2001

4) Fujiki, H.: A Hidden Design Problem in the Japanese Public Works, Operations Research, 60, 2, pp.113-129, 2009.7 (in Japanese) 藤木寛人: 裏設計問題のメカニズムと建設産業の課題, 経営研究, 60(2), pp.113-129, 2009.7

5) Furusaka, S. and Kaneta, T.: Study on specialty subcontractor's behaviors, Journal of Architecture and Planning (Transactions of AIJ), No.534, pp.227-232, 2000.8 (in Japanese) 古阪秀三，金多隆：専門工事業者の企業行動と協力会に対する意識に 関する研究, 日本建築学会計画系論文集, 第 534 号, pp.227-232, 2000.8

6) Nagashima, K. and Ando, M.: Specialist Contractors' Involvement in Project Configuration and the Changing Industrial Structure, Symposium on building construction and management of projects (Transactions of AIJ), 15 th, pp.119-124, 1999 (in Japanese) 長嶋和久, 安藤正雄: 専門工事業者のプロジェクト関与に関する研究, 日本建築学会建築経済委員会, 第 15 回建築生産シンポジウム, pp.119-124, 1999

7) Hirano, Y., Urae, S., Furusaka, S., Ikeda, S. and Nagasako, T.: A Study on Responsibility/Liability structure among participating Parties in US construction Contract Conditions, Symposium on building construction and management of projects (Transactions of AIJ), 31 th, pp.175-182, 2015 (in Japanese)

平野吉信, 浦江真人, 古阪秀三, 池田諭, 長廻拓史, 米国の工事請負 契約約款における各主体間の役割構造に関する一考察，日本建築学会 建築社会システム委員会, 第 31 回建築生産シンポジウム, pp.175-182, 2015

8) Kanisawa, H.: Management of construction skill, Furusaka, S. (Ed.) Handbook of Building Construction and Management of Projects, pp.309-315, 2007 (in Japanese)

蟹澤宏剛，技能のマネジメント，古阪秀三編：建築生産ハンドブック， pp.309-315, 2007

9) Imae, M. and Ando, M.: Study of the Specialist Sub-contractor's Techniques and Skills in the Stock-oriented Market: Specialist Sub-contractor's Architecture, Symposium on building construction and management of projects (Transactions of AIJ), 23 ${ }^{\text {rd }}$, pp.269-274, 2007 (in Japanese)

今江麻衣，安藤正雄：ストック活用型社会における専門工事業の技術 技能の研究, 日本建築学会建築経済委員会, 第 23 回建築生産シンポジ ウム, pp.269-274, 2007

10) Ando, M., Yokota, T. and Furusaka, S.: Façade Engineering Practice in Europe, Symposium on building construction and management of projects (Transactions of AIJ), 18 ${ }^{\text {th }}$, pp.131-138, 2002 (in Japanese) 安藤正雄, 横田暉生, 古阪秀三: ヨーロッパにおけるファサード・エ ンジニアリングの成立とその業務, 日本建築学会建築経済委員会, 第 18 回建築生産シンポジウム, pp.131-138, 2002

11) Inoue, A., Matsumura, S. and Seike, T.: The requirements to Establish Façade Engineering in Japan, Symposium on building construction and management of projects (Transactions of AIJ), $18^{\text {th }}$, pp.139-144, 2002 (in Japanese)

井上朝雄, 松村秀一, 清家剛：日本におけるファサード・エンジニア リングの成立要件, 日本建築学会建築経済委員会, 第 18 回建築生産シ ンポジウム, pp.139-144, 2002

12) Takahashi, M. and Furusaka, S.: Implementing Registered Architects Law in Japan under Current Sense of Architects' Profession in the US and Europe, Journal of Architecture and Planning (Transactions of AIJ), No.533, pp.281-288, 2000.7 (in Japanese)

高橋栄人, 古阪秀三: わが国建築士制度における欧米建築家の職能の 現代的意義に関する研究，日本建築学会計画系論文集，第 533 号, pp.281-288, 2000.7

13) Furusaka, S. et al.: The Analysis of the Present State of Diversified Professions, Symposium on building construction and management of projects (Transactions of AIJ), 23 rd, pp.255-260, 2007 (in Japanese)

古阪秀三, 宮井周平, 水川尚彦, 金多隆, 石井泰一郎, 大崎純, 原田 和典：多様化する職能の現状分析, 日本建築学会建築経済委員会, 第 23 回建築生産シンポジウム, pp.255-260, 2007

14) Miyai, S. et al.: Discussion on classification of diverse professions and their generation process, Journal of Architecture and Planning (Transactions of AIJ), Vol.75, No.650, pp.1291-1292, 2010.4 (in Japanese) 宮井周平，水川尚彦，古阪秀三，金多隆，石田泰一郎，大崎純，原田 和典：多様化する職能の類型化と生成過程の考察, 日本建築学会計画 系論文集，第 75 巻，第 650 号, pp.1291-1292, 2010.4

15) Kaneta, T. et al.: Concept of Architectural Services to Find New Business, Research Reports of Kinki division (Transactions of AIJ), pp.649-652, 2008 (in Japanese)

金田隆，宮井周平，古阪秀三，原田和典，大崎純，石田泰一郎，水川 尚彦: 建築設計業務の階層構造分析と新職能の可能性, 平成 20 年度日 本建築学会近畿支部研究報告集, pp.649-652, 2008

16) Nishino, S., Takamatsu, S., Furusaka, S. and Hirano, Y.: Decision Making Process of Design Contents in Tokyo Metropolitan Art 
Museum, Journal of Architecture and Planning (Transactions of AIJ), Vol.75, No.654, pp.1979-1986, 2010.8 (in Japanese) 西野佐弥香, 高松伸, 古阪秀三, 平野吉信 : 東京都美術館の建築プロ セスにおける設計内容の確定過程, 日本建築学会計画系論文集, 第 75 巻, 第 654 号, pp.1979-1986, 2010.8

17) Nishino, S., Takamatsu, S., Furusaka, S. and Hirano, Y.: Decision Making Process of Design Contents in Kyoto Takaragaike Prince Hotel, Journal of Architecture and Planning (Transactions of AIJ), Vol.76, No.659, pp.149-157, 2011.1(in Japanese)

西野佐弥香, 高松伸, 古阪秀三, 平野吉信 : 京都宝ヶ池プリンスホテ ルの建築プロセスにおける設計内容の確定過程, 日本建築学会計画系 論文集，第 76 巻，第 659 号, pp.149-157, 2011.1

18) The procurement of Sheet Metal in Elevator industry, Sheet metal \& fabricator, 50(12), 607, 2006.12 (in Japanese)

昇降機業界の板金部材調達の現状, Sheet metal \& fabricator, 50(12), $607,2006.12$

19) Nikkei Information Strategy, , pp.124-127, 2009.4 (in Japanese) 日経情報ストラテジー, pp.124-127, 2009.4

20) Japan Elevator Association: Report on the number of installed elevators in 2014 (in Japanese)

一般社団法人日本エレベータ協会 : 2014 年度昇降機設置台数等調査結 果報告, Elevator Journal, No.6, pp.35-44. 2015.07

21) International Association of Elevator Consultants (IAEC)website(http://www.iaec.org/IAEC/International_Association _of_Elevator_Consultants_IAEC_Membership.html) 


\title{
STUDY ON THE DESIGN ASSISTANCE BY JAPANESE SUBCONTRACTORS
}

Japan and the US case studies in the elevator design

\author{
Masatoyo OGASAWARA* and Tomonari YASHIRO** \\ * Project Assist. Prof., Institute of Industrial Science, The University of Tokyo, M. Arch. \\ ** Prof., Institute of Industrial Science, The University of Tokyo, Dr. Eng.
}

This paper investigates so-called "Design Assistance (sekkei kyoryoku)" by Japanese subcontractors. The tasks and responsibilities of subcontractors in Design Assistance, the information generated through Design Assistance, and the difference between Design Assistance in Japan and Consultation in US are focused. Our previous paper pointed out that Japanese design organizations tend to utilize Design Assistance by the subcontractors, whereas US design organizations are more likely to distribute design tasks among specialized consultants. In this paper, the elevator industry is focused as the typical industry indicating the clear difference of the task distribution between Japanese Design Assistance and the US Consultation. In Japan, elevator companies are regarded as subcontractors as they provide design, manufacturing, installation, and maintenance services. They offer the product design information and analysis for free. It is called Design Assistance, as they hope to be specified and installed in future construction. In the US, by contrast, Vertical Transportation Consultants provide design service to the architects especially for customized elevators. In Japanese cases, five major elevator companies are selected. Thirteen people are interviewed. In the US cases, twenty-five Vertical Transportation Consultants were approached, and five of them responded to the inquiry (Table4).

First, the tasks and responsibilities of subcontractors in Design Assistance are clarified. We confirmed the subcontractors provide the design information based on the Design Assistance free of charge. The subcontractors do not have a primal responsibility of their design information, especially to the owner of the project. It results in a confusion of responsibilities between the architect and the subcontractor.

Second, two types of the information gathering process through the Design Assistance is confirmed. One is the information generated by the subcontractor and provided to the architect, such as drawings, specifications, analysis, cost estimation, and presentation images (Table1). The other is the information provided from the architect to the subcontractor. The Design Assistance is one of the best opportunities for subcontractors to acquire "needs" of the owners, which is typically not obtained by the sales department of subcontractors. It is utilized for the development of new products.

Third, the difference between Design Assistance in Japan and Consultation in US are focused. In this paper, the basic services of the consultants were investigated, through the website of the consultants on the list of International Association of Elevator Consultants (IAEC). In US, an assessment and inspection oriented service, such as Maintenance Review, Assessment, Litigation and Inspection, and project management service for elevator installation are available (Table3). There are far more significant opportunities in modernization than new construction. The elevator manufacturers and the vertical transportation consultants are separate entities, which make smooth information exchange difficult compared to the Japanese environment (Fig.4). 